Available online at GSC Online Press Directory

GSC Biological and Pharmaceutical Sciences

e-ISSN: 2581-3250, CODEN (USA): GBPSC2

Journal homepage: https://www.gsconlinepress.com/journals/gscbps

(RESEARCH ARTICLE)

\title{
Lyophilization as an alternative method for preservation of some continuous cell cultures
}

\author{
Shendy M. B., Taha A. E. * , El Sayed E. L., Albehwar A. M. and Abou El Naga H. I. \\ Veterinary Serum and Vaccine Research Institute (VSVRI), Abbasia, Cairo, Egypt. P.O. Box 131. \\ Publication history: Received on 09 August 2018; revised on 28 August 2018; accepted on 07 September 2018
}

Article DOI: https://doi.org/10.30574/gscbps.2018.5.1.0079

\begin{abstract}
This work is a trial to provide lyophilization as a simple method for preservation of continuous cell lines instead of the freezing process in liquid nitrogen. Comparative evaluation of lyophilized African green monkey kidney (VERO), baby hamster kidney (BHK) and Madin Darby bovine kidney (MDBK) cell lines and those preserved by freezing in liquid nitrogen was carried out. Such evaluation on 6 months intervals revealed that both of lyophilized cell cultures showed delayed cell adhesion to the culture surface extending to 2-3 days post culturing while propagated and frozen cells adhered to the culture surface within few hours. However there were an increased number of adhered viable cells in case of loading of cells using trehalose and sucrose on days post culturing. In addition cultured lyophilized cells which loaded by trehalose or sucrose exhibited abnormal shape (showing cell rounding) in comparison to the other cultures. Also cell dispersing of confluent sheets of cultured lyophilized cells were found to take longer time (one hour) than that required to other cultures (few minutes) even on using EDTA and incubation at $37{ }^{\circ} \mathrm{C}$. Further studies are needed to investigate the biological behavior or cell changes which may be occurred through the lyophilization process in addition to study the susceptibility of such cells to virus infection. Depending on these facts it could be said that lyophilization is not valid for VERO, BHK and MDBK which usually used for preparation of virus vaccine in stationary or roller systems. It also could be suggested that preservation of cell lines by lyophilization may be of value in cell culturing suspension system.
\end{abstract}

Keywords: Preservation; Cell Cultures; Lyophilization

\section{Introduction}

Continuous cell cultures are used to be an essential component of a routine work in the lab. They provide a good system for isolation and propagation of majority of human and animal viruses. In addition, they are used in production of viral antigens for various serological and molecular techniques. All types of cells could be cryopreserved and stored in liquid nitrogen (LN) tanks, in nitrogen vapor phase or in $-80{ }^{\circ} \mathrm{C}$ freezers $[1,2,3]$. These traditional methods of cryopreservation is prone to transient warming events and various other hazards, such as cross-contamination [4, 5] and cell losses by 20 to $30 \%$ [6]. Interestingly, lyophilization (freeze-drying) of the cells could theoretically substantially minimize the hazards related to storage at ultra-low temperatures, thus simplifying the procedure, decreasing expenses and taking into consideration better stockpiling and transport. These characteristics are especially important when long standing keeping is required. In addition, lyophilization does not include the defrosting process to which cell damage is attributed, particularly at large volumes (e.g. from recrystallization). Lyophilization has been employed in the preparation of some vaccines as one of the most important techniques for the preservation of heat-sensitive biological ingredients. Contrasted with different techniques, lyophilization has some well-known advantages; including sample stability at room temperature, defined porous product structure, easy reconstitution by increasing of water or aqueous solution, and simple transportation [7].

\footnotetext{
*Corresponding author

E-mail address: ashraf.eldakhly@yahoo.com
} 
Mammalian cells typically do not survive drying but biomolecules are often well preserved. For example, spermatozoa chromatin structure in freeze-dried sperm, is largely intact and can be used to fertilize an oocyte by means of intracytoplasmic sperm inoculation [8]. The potential of lyophilization have been shown to preserve genetic information of somatic and stem cells [9, 10, and 11]. Red blood corpuscles (RBCs) overloaded by the disaccharide trehalose can be lyophilized and rehydration of the lyophilized RBCs resulted in about 55\% survival, built on the percentage of hemolysis [12]. The success of lyophilization of the mammalian cells was essentially dependent on the use of trehalose.

Anhydrobiotic organisms can tolerate the shortage of water because of their capability to construct great quantities of trehalose [13]. To reduce the damages of both desiccation and hypothermia through the lyophilization procedure, polyvinyl pyrrolidine (PVP40) was added as a protectant. The polyvinyl pyrrolidine (PVP40) can obstruct sucrose crystallization and stabilize the glassy structure of sugar [14].During the rehydration of lyophilized cells Phosphate buffered saline (PBS) could be used as rehydration solution[7,15]. Leslie et al [16] mentioned that the non-reducing disaccharides such as sucrose and trehalose play an important role in protection of biological membranes, liposomes and some intact cells from adverse effects of freezing and drying. This work aims to provide an alternative method for preservation of continuous cell lines other than the use of liquid nitrogen to avoid the possible hazards and disadvantages of using liquid nitrogen as a method of cells preservation.

\section{Material and methods}

\subsection{Continuous cells cultures}

Propagated and liquid nitrogen frozen African Green Monkey Kidney (VER0), Baby Hamster Kidney (BHK-21) and Madin Darby Bovine Kidney (MDBK) cell lines were supplied by Veterinary Serum and Vaccine Research Institute (VSVRI), Abbasia, Cairo, Egypt. These cell lines were used at a density of $4.8 \times 10^{4} \mathrm{cells} / \mathrm{ml} \mathrm{in} 25 \mathrm{~cm}^{3}$ tissue culture flasks using Minimum Essential Medium (MEM), Gibco, USA.With10 \% (v/v) fetal calf serum (FCS) and incubated at $37{ }^{\circ} \mathrm{C}$ in $5 \% \mathrm{CO}_{2}$ atmosphere. After $48 \mathrm{~h}$ incubation, non-adherent cells were discarded, when the cells grew up to $80 \%-90 \%$ confluence, the cells were harvested with $0.25 \%(\mathrm{w} / \mathrm{v})$ trypsin.

\subsection{Preparation of cell lines for the lyophilization process}

\subsubsection{Loading with trehalose}

Each harvested cell line was incubated with $100 \mathrm{mmol} / \mathrm{L}$ concentration of trehalose solution (Sigma-Aldrich) at $37^{\circ} \mathrm{C}$ in 5\% CO2 atmosphere for $24 \mathrm{~h}$ [17].

\subsubsection{Loading with sucrose}

Each of the harvested three cell lines was incubated with $100 \mathrm{mmol} / \mathrm{L}$ concentration of sucrose solution (Sigma-Aldrich) at $37^{\circ} \mathrm{C}$ in $5 \% \mathrm{CO} 2$ atmosphere for $24 \mathrm{~h}$.

\subsection{Freeze-drying suspension}

The freeze-drying suspension was composed of 30\% PVP40 , $100 \mathrm{mmol} / \mathrm{L}$ trehalose while $100 \mathrm{mmol} / \mathrm{L}$ sucrose was used in case of loading by sucrose, then the cells were suspended at a volume ratio of 2:1:2 with cell concentration $10^{6}$ cells/ml [17].

\subsection{Freeze-drying process}

The lyophilizing technique was carried out on Tofflon lyophilizer apparatus. A total of $2.5 \mathrm{ml}$ freeze-drying system was filled into a sterilized glass vials covered with a semipermeable rubber stopper. The glass vial's inner diameter was 1.9 $\mathrm{cm}$. The vials were placed on the shelf of the freeze-dryer, which had been precooled to $-60{ }^{\circ} \mathrm{C}$, so that quick freezing could be realized [18]. After cooling for $2 \mathrm{~h}$, the primary drying began. The shelf temperature was set at $-32^{\circ} \mathrm{C}$, and the vacuum was controlled under $10 \mathrm{~Pa}$ [19]. The primary drying process lasted for $16 \mathrm{~h}$. Then the shelf was wormed up to $20{ }^{\circ} \mathrm{C}$ at a rate of $0.2^{\circ} \mathrm{C} / \mathrm{min}$ and held for $6 \mathrm{~h}$. After freeze-drying, the vials were sealed and kept at room temperature for $2 \mathrm{~h}$ [17] then kept at $-20^{\circ} \mathrm{C}$ till subjected for evaluation of the effect of lyophilization process.

\subsection{Rehydration}

The lyophilized samples were equilibrated in $0.5 \mathrm{ml}$ rehydration solution composed of $30 \%$ PVP40, $100 \mathrm{mmol} / \mathrm{L}$ trehalose in case of loading by trehalose and $100 \mathrm{mmol} / \mathrm{L}$ sucrose in case of loading by sucrose, and PBS buffer at a 
volume ratio of 2:1:2 for $5 \mathrm{~min}$, then supplemented with $4.5 \mathrm{ml}$ rehydration solution composed of MEM containing 20 $\%(v / v)$ Fetal Calf Serum [17].

\section{Results and discussion}

In this work culturing of lyophilized cell cultures (VERO, BHK and MDBK) showed delayed cell adhesion to the culture surface extending to 2-3 days post culturing while the sub-cultured non-lyophilized cells adhered to the culture surface within few hours. It was obvious that the cultured lyophilized cells by using trehalose or sucrose exhibited abnormal shape (showing cell rounding) as shown in figures (1,2 and 3).

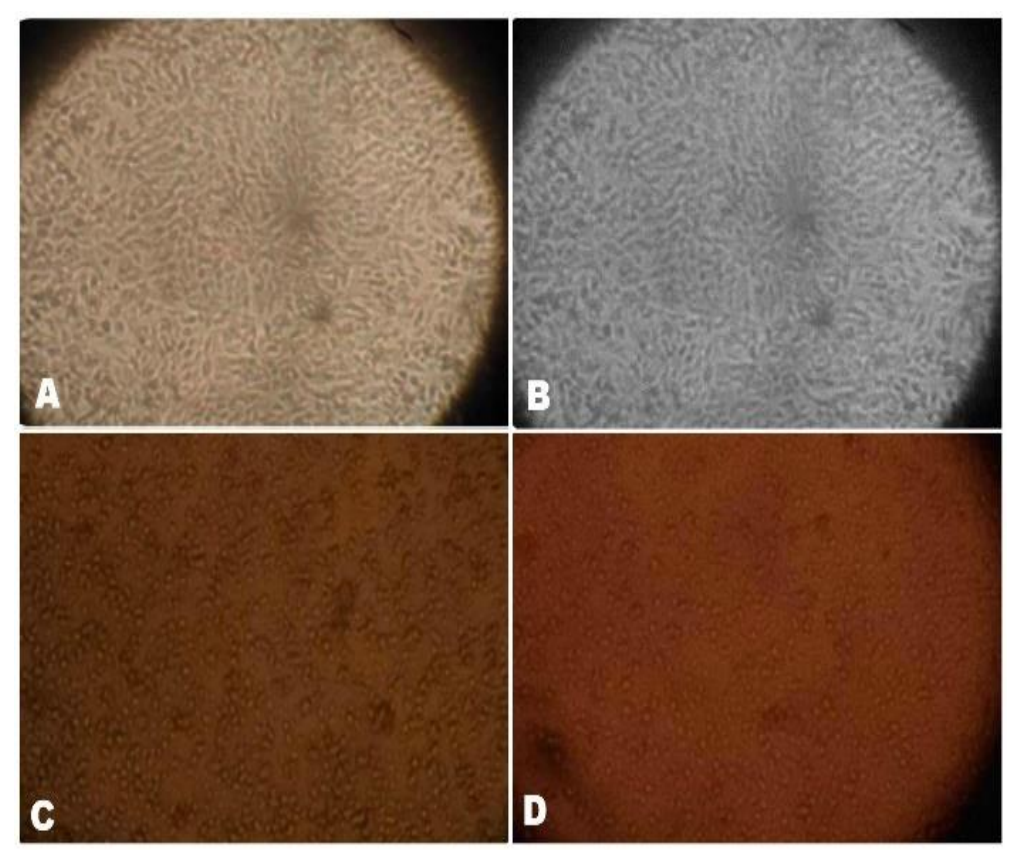

Figure 1 Non-lyophilized VERO cells (A), preserved VERO cells in liquid nitrogen (B), lyophilized VERO cells using trehalose (C) and lyophilized VERO cells using sucrose (D)

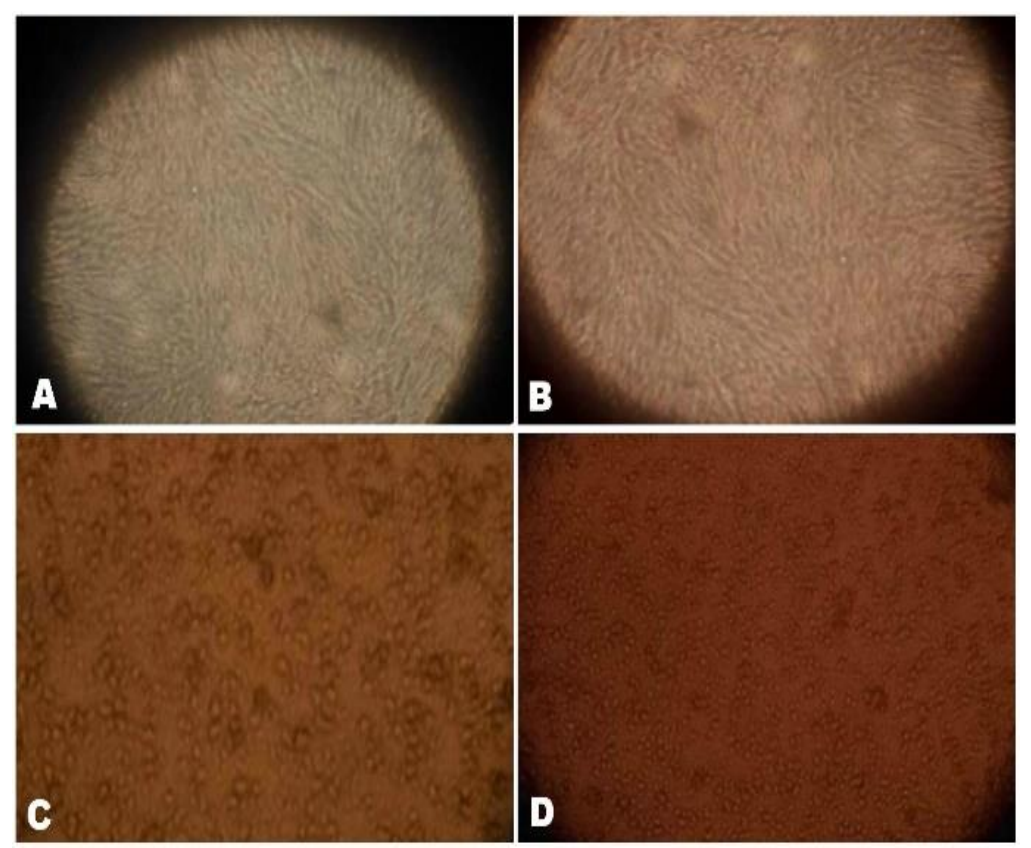

Figure 2 Non-lyophilized BHK cells (A), preserved BHK cells in liquid nitrogen (B), lyophilized BHK cells using trehalose (C) and lyophilized BHK cells using sucrose (D) 

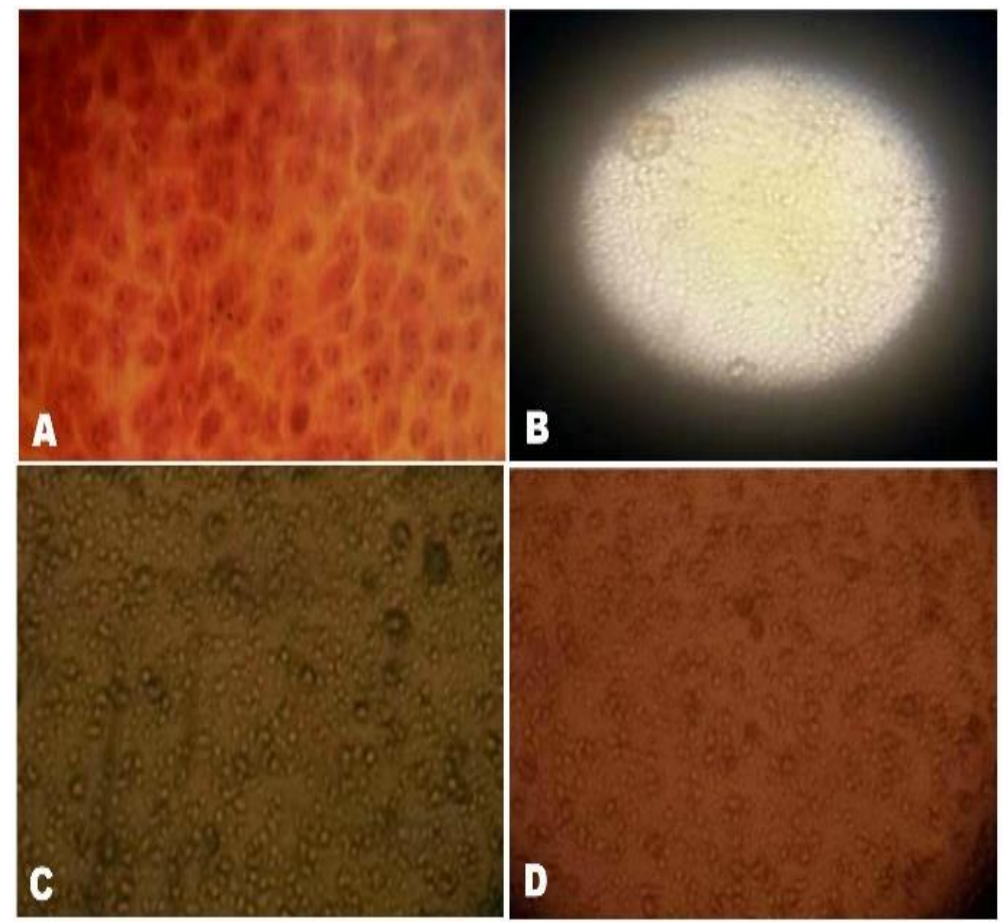

Figure 3 Non-lyophilized MDBK cells (A), preserved MDBK cells in liquid nitrogen (B), lyophilized MDBK cells using trehalose (C) and lyophilized MDBK cells using sucrose (D)

Table 1 Cell counting of preserved cell cultures

\begin{tabular}{|c|c|c|c|c|c|c|c|c|}
\hline \multirow[t]{3}{*}{ Tested cells } & & \multicolumn{7}{|c|}{ Cells number $/ \mathbf{m l}^{*}$} \\
\hline & & \multirow{2}{*}{$\begin{array}{l}\text { Before } \\
\text { preservation }\end{array}$} & \multicolumn{5}{|c|}{ After lyophilization and storage at-80 ${ }^{\circ} \mathrm{C} / \mathrm{MPP}^{* *}$} & \multirow[b]{2}{*}{$6^{\text {th }}$ MPP } \\
\hline & & & $1^{\text {st }}$ MPP & $2^{\text {nd }}$ MPP & $3^{\text {rd }}$ MPP & $4^{\text {th }}$ MPP & $5^{\text {th }}$ MPP & \\
\hline \multirow{3}{*}{$\begin{array}{l}\text { Lyophilized } \\
\text { cells using } \\
\text { trehalose }\end{array}$} & VERO & \multirow{3}{*}{4.8} & 3.37 & 3.35 & 3.30 & 3.12 & 3.00 & 3.00 \\
\hline & BHK & & 2.98 & 2.72 & 2.6 & 2.40 & 2.10 & 2.00 \\
\hline & MDBK & & 3.87 & 3.10 & 2.98 & 2.80 & 2.70 & 2.64 \\
\hline \multirow{3}{*}{$\begin{array}{l}\text { Lyophilized } \\
\text { cells using } \\
\text { sucrose }\end{array}$} & VERO & \multirow{3}{*}{4.8} & 2.97 & 2.50 & 2.35 & 2.20 & 2.23 & 2.10 \\
\hline & BHK & & 2.32 & 2.30 & 2.28 & 2.25 & 2.21 & 2.00 \\
\hline & MDBK & & 2.75 & 2.65 & 2.48 & 2.42 & 2.35 & 2.05 \\
\hline \multirow{3}{*}{$\begin{array}{l}\text { Liquid } \\
\text { nitrogen } \\
\text { frozen cells }\end{array}$} & VERO & \multirow{3}{*}{4.8} & 4.21 & 3.53 & 3.40 & 3.25 & 3.12 & 3. 00 \\
\hline & BHK & & 3.22 & 2.98 & 2.47 & 2.26 & 2.15 & 2.15 \\
\hline & MDBK & & 3.91 & 3.76 & 3.60 & 2.93 & 2.58 & 2.55 \\
\hline
\end{tabular}

The number of adhered cells $/ \mathrm{ml}$ in case of using trehalose after six months of lyophilization were $3.0 \times 10^{4,} 2.0 \times 10^{4}$ and $2.64 \times 10^{4}$ for lyophilized VERO, BHK and MDBK cells respectively (Table 1).While in case of using sucrose instead of trehalose the number of adhered cells/ml were $2.1 \times 10^{4}, 2.0 \times 10^{4}$ and $2.05 \times 10^{4}$ for lyophilized VERO, BHK and MDBK cells after six month of lyophilization respectively (Table 1). At the same time the cell number $/ \mathrm{ml}$ after freezing and storage at liquid nitrogen were $3.0 \times 10^{4}, 2.15 \times 10^{4}$ and $2.55 \times 10^{4}$ for VERO, BHK and MDBK cells respectively (Table 1 ). There are no available data agree or discuss the present obtained results. Although it was stated that lyophilization of the cells could theoretically substantially diminish the dangers related to storage at ultra-low temperatures, thus simplifying the procedure, decreasing expenses and taking into consideration, stockpiling and transport [7]. 
There are two main assumptions demonstrate the protective effect of trehalose and sucrose as protectants to mammalian cells, where non-reducing disaccharides (trehalose and sucrose) act in drought by water-replacement hypothesis and vitrification hypothesis [20]. Quaak et al, [21] mentioned that non-reducing sugars as trehalose and sucrose were preferred as protectants for desiccated objects since they are less reactive than reducing monosaccharaides or disaccharides. When a comparison was made between trehalose and sucrose as protectant, it was found that the results of trehalose were better than those of sucrose (Table 1) and (Figure 4, 5 and 6). This could be attributed to the hydration radius of trehalose which is 2.5 times more than that of sucrose, indicating that 2.5 times the concentration of sucrose is needed to give the same protein protection effect as trehalose [22]. Also the trehalose has the ability to interact more than sucrose with both water and proteins and in the same time has the ability to replace water molecules which are attached to carbonyls at the phospholipid bilayer of cell membranes unlike the sucrose [23, 24].

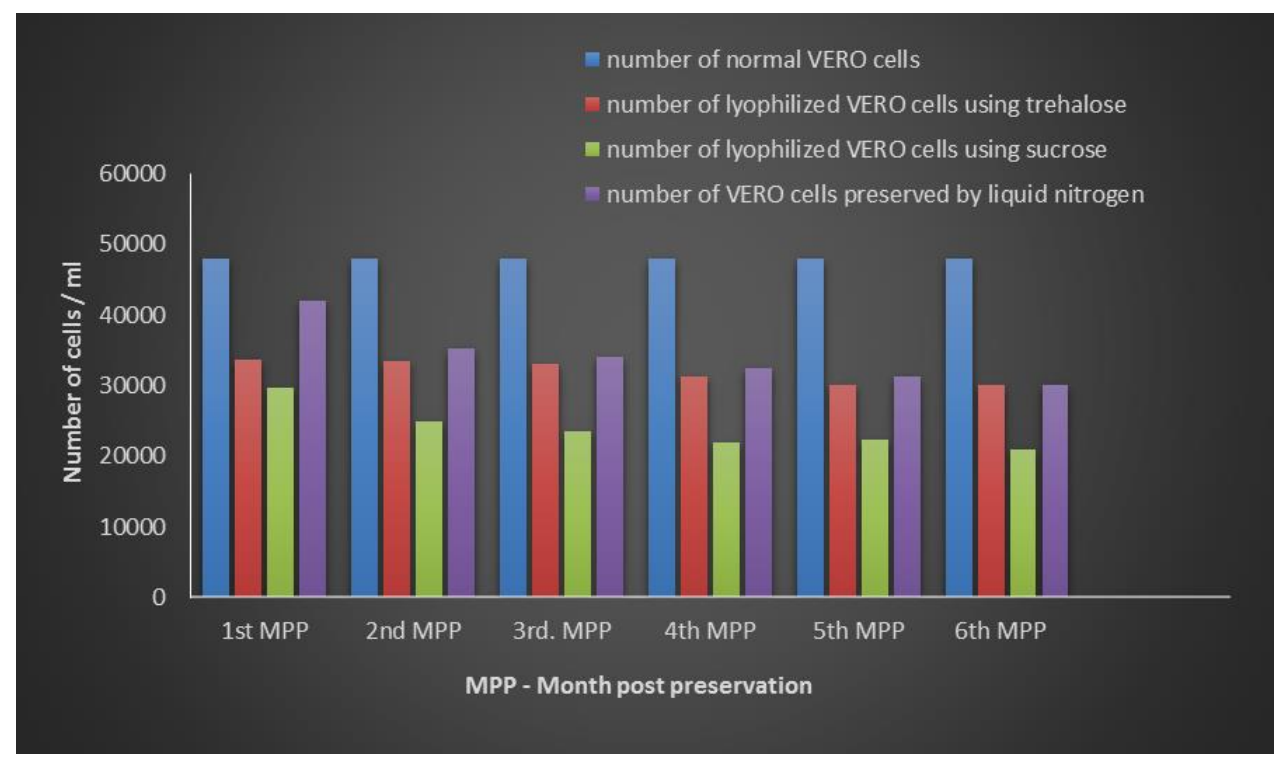

Figure 4 Cell counting of VERO cell cultures

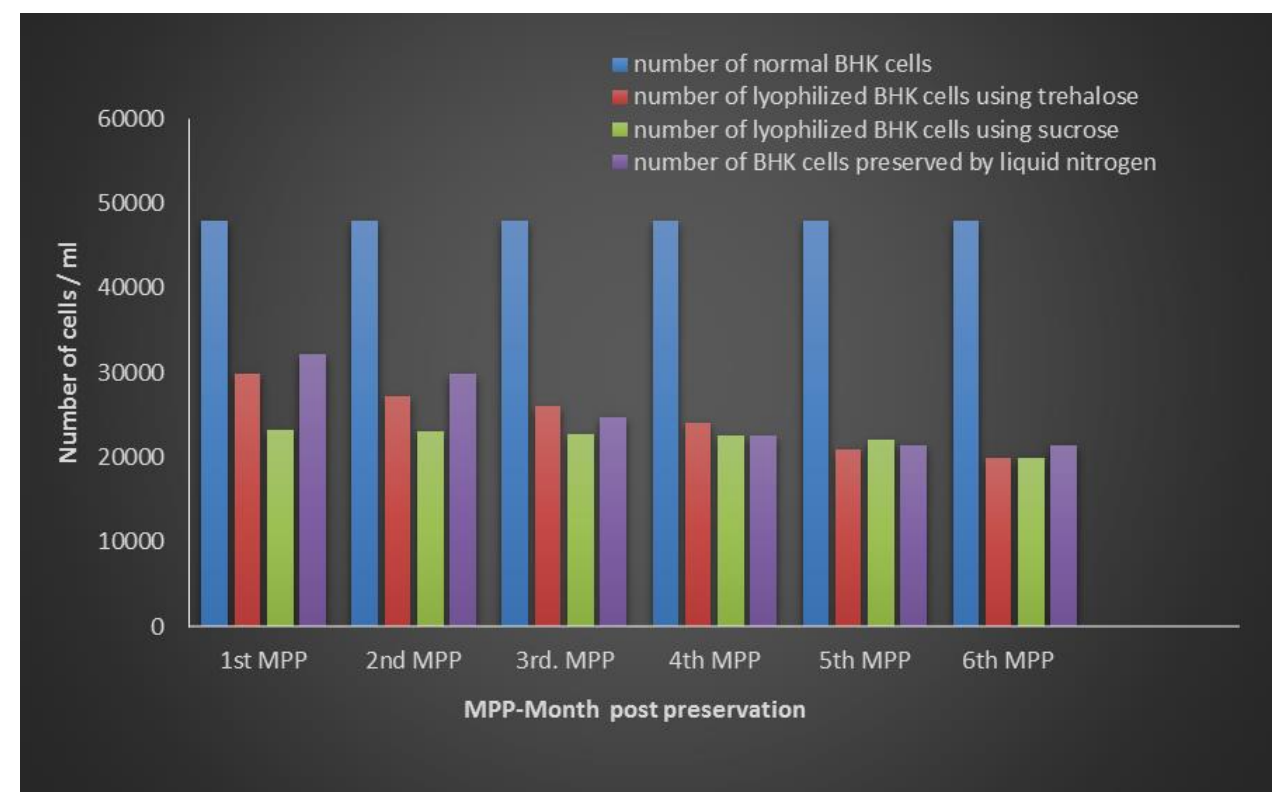

Figure 5 Cell counting of BHK cell cultures 


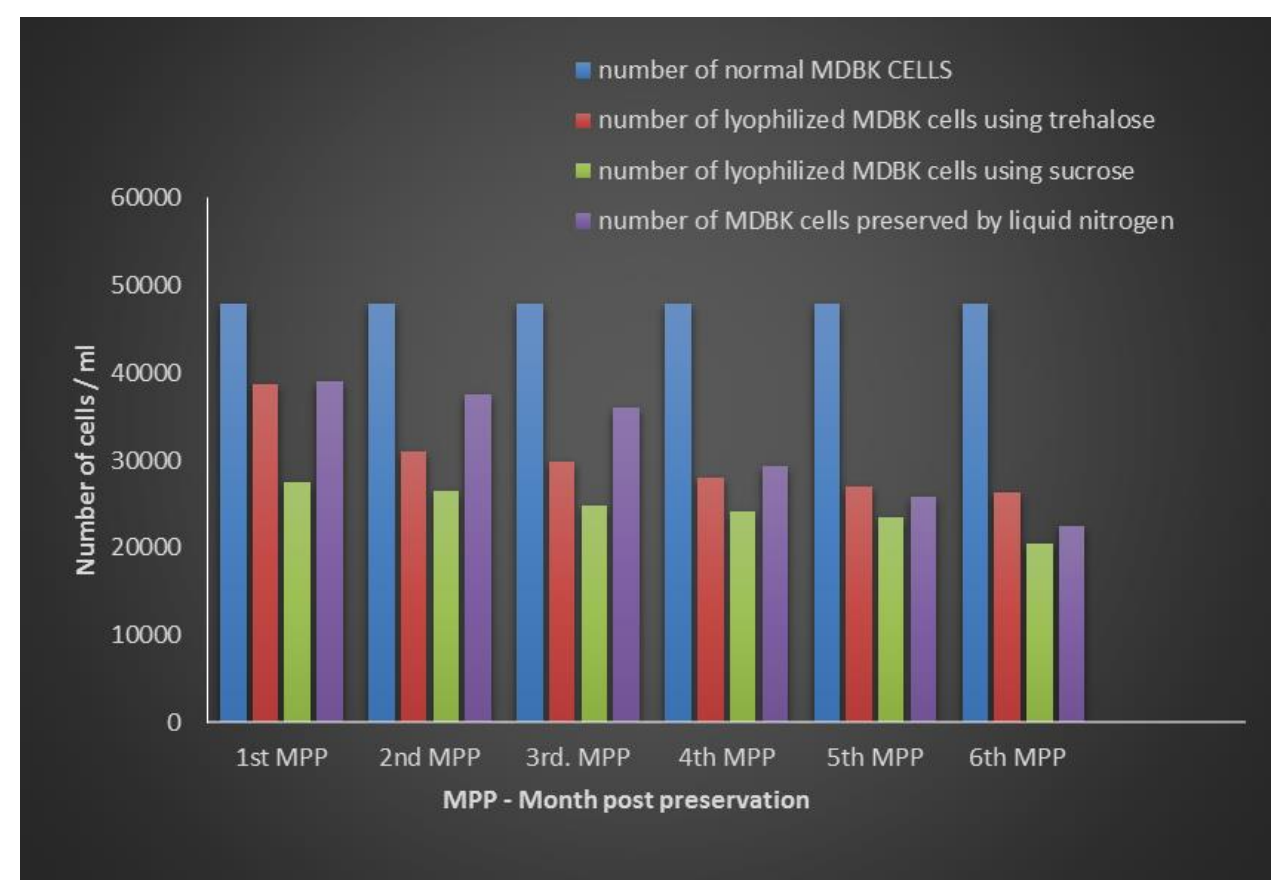

Figure 6 Cell counting of MDBK cell cultures

On the other side there was less gradual decline in cell counting in all methods of cell culture preservation which could be attributed to change of the optimal cell culture viability environment. It was noticed that BHK cells were the most affected by the three methods of preservation showing more decline in cell counting than Vero and MDBK cells. Anyhow, it is clear that cell culture preservation in liquid nitrogen is the best one to maintain normal adhesion to the culture surface with normal shape and normal behavior on dispersing during the subculture process. So, it is recommended that more researches and investigations are needed in that respect regarding changing in cells multiplication behavior, biological and physiological cell functions and susceptibility to different viruses, and the possibility of using lyophilization for preserving cells which are planned to be used in cell suspension technique.

\section{Conclusion}

It could be concluded that the preservation of VERO, BHK and MDBK cells by lyophilization may be suitable in cell culturing suspension system more than stationary or roller culture systems.

\section{Compliance with ethical standards}

\section{Acknowledgments}

The authors wish to thank Professor Mohamed Hassan Khodeir for performing support to this work.

\section{Disclosure of conflict of interest}

There is no conflict of interest.

\section{References}

[1] Choi CW, Kim BS, Seo JH, Shin SW, Kim YH and Kim JS. (2001). Long term engraftment stability of peripheral blood stem cells cryopreserved using the dump-freezing method in a $-80{ }^{\circ} \mathrm{C}$, mechanical freezer with $10 \%$ dimethyl sulfoxide. Int. J. Hematol, 73(2), 245-50.

[2] Halle P, Tournilhac O, Knopinska-Posluszny W, Kanold J, Gembara P, Boiret N, Rapate C, Berger M, Travade P, Angielski S, Bonhomme J and Deméocq F. (2001).Uncontrolled-rate freezing and storage at $-80{ }^{\circ} \mathrm{C}$, with only 3.5percent DMSO in cryoprotective solution for 109 autologous peripheral blood progenitor cell transplantations. Transfusion, 41(5), 667-673. 
[3] Rogers I, Sutherland D R, Holt D, Macpate F, Lains A and Hollowell S. (2001). Human UC-blood banking: impact of blood volume, cell separation and cryopreservation on leukocyte and CD34 (+) cell recovery. Cytotherapy, 3(4), 269-76.

[4] Bielanski A, Bergeron H, Lau PC and Devenish J. (2003). Microbial contamination of embryos and semen during long term banking in liquid nitrogen. Cryobiology, 46 (2), 146-152.

[5] Morris GJ (2005). The origin, ultrastructure, and microbiology of the sediment accumulating in liquid nitrogen storage. Cryobiology, 50(3), 231-238.

[6] Laroche V. McKenna DH, Moroff G, Schierman T, Kadidlo D and McCulloogh J (2005). Cell loss and recovery in umbilical cord blood processing: a comparison of postthaw and postwash samples. Transfusion, 45(12), 19091916.

[7] Xiao HH, Hua TC and Li J. (2004). Freeze drying of mononuclear cells and whole blood of human cord blood. Cryo Letters, 25(2), 111-120.

[8] Wakayama T, and Yanagimachi R. (1998). Development of normal mice from oocytes injected with freeze-dried spermatozoa. Nat. Biotechnol, 16, 639-641.

[9] Loi P, Kazutsugu M, Grazyna P, Michael C, Josef FJ ,Yehudith N and Amir A. (2008). Freeze-dried somatic cells direct embryonic development after nuclear transfer. PLoS One 3, e2978.

[10] Buchanan SS, Pyatt DW and Carpenter JF. (2010). Preservation, differentiation and clonogenic potential of human hematopoietic stem and progenitor cells during lyophilization and ambient storage. PLoS One 5, e12518.

[11] Bissoyi Akalabya , Awanish Kumar, Albert A Rizvanov, Alexander Nesmelov, Oleg Gusev, Pradeep Kumar Patra and Arindam B. (2016). Recent advances and future direction in lyophilization and desiccation of mesenchymal stem cells. Stem Cells Int., 1-9.

[12] Zsolt T, Gyana RS, Mitali B, Rachna B, Erika L, Roberta N, Hung VL, Denis MD, Azadeh K, Fern T, John HC and Nelly MT. (2005). Preservation of trehalose-loaded red blood cells by lyophilization. Cell Preservation Technology Journal, 3 (2), $96-111$.

[13] Alpert P (2006). Constraints of tolerance, why are desiccation -tolerant organisms so small or rare? J. Exp .Biol. 209 (9), 1575-1584.

[14] Zeng XM, Martin GP and Marriott C. (2001). Effects of molecular weight of polyvinylpyrrolidone on the glass transition and crystallization of co-lyophilized sucrose. Int. J. Pharm., 218(1-2), 63-73.

[15] Li J, Hua TC and GU XL. (2005). Morphology study of freeze-drying mononuclear cells of human cord blood. CryoLetters, 26 (3), 193-200.

[16] Leslie SB, Teter SA, Crowe LM and Crowe JH. (1994). Trehalose lowers membrane phase transitions in dry yeast cells. Biochim. Biophys. Acta, 1192, 7-13.

[17] Shao-zhi Z, Huan Q, Zhen W, Ju-li F, Qian Z, Guang-ming C, Rui L, Shan F and Jie S. (2010). Preliminary study on the freeze-drying of human bone marrow-derived mesenchymal stem cells. J. Zhejiang Univ. Sci. Bv. 11 (11).

[18] Wang J and Zhang H. (2007). The influence of one-step $-80{ }^{\circ} \mathrm{C}$ cryopreservation on the osteogenesis differentiation ability of human bone marrow-derived mesenchymal stem cells. Guangdong Med., 28(3), 365367.

[19] Zhou XL, Zhu H, Zhang SZ, Zhu FM, Chen GM and Yan LX. (2007). Freeze-drying of human platelets: influence of saccharide, freezing rate and cell concentration. Cryo Letters., 28(3), 187-196.

[20] Sakurai M, Furuki T and Akao KI. (2008). Vitrification is essential for anhydrobiosis in an African chironomid, Polypedilum vanderplanki. Proceedings of the National Academy of Sciences of the United States of America, 105(13), 5093-5098.

[21] Quaak SGL, Haanen JBAG, Beijnen JH and Nuijen B. (2010). Naked plasmid DNA formulation: effect of different disaccharides on stability after lyophilisation. AAPS, Pharm. SciTech., 11(1), 344-350.

[22] Sola-Penna M and Roberto Meyer-Fernandes J. (1998). Stabilization against thermal inactivation promoted by sugars on enzyme structure and function: why is trehalose more effective than other sugars? Archives of Biochemistry and Biophysics. 360 (1), 10-14.

[23] Del CLM, Amalfa F, Nuñez AM, Díaz S, Biondi De Lopez AC and Disalvo EA. (2000). Effect of trehalose and sucrose on the hydration and dipole potential of lipid bilayers. Biophysical Journal, 78 (5), 2452-2458. 
[24] Lerbret A, Bordat Affouard Hédoux A, Guinet $Y$ and Descamps M. (2007). How do trehalose, maltose, and sucrose influence some structural and dynamical properties of lysozyme? Insight from molecular dynamics simulations. Journal of Physical Chemistry, 111(31), 9410-9420.

\section{How to cite this article}

Shendy MB, Taha AE, El Sayed EL, Albehwar AM and Abou El Naga HI. (2018). Lyophilization as an alternative method for preservation of some continuous cell cultures. GSC Biological and Pharmaceutical Sciences, 5(1), 01-08. 